\title{
THE DOCK CONSTRUCTION OF INTER-ISLAND IN INDONESIA
}

\author{
Mohamad Fajrunnajah \\ Civil Engineering Department, Faculty of Technic, University of Muhammadiyah Malang, 65145, \\ Indonesia \\ e-mail :pajruuun@gmail.com
}

\begin{abstract}
Sea transportation is important to support economic wheels and equitable distribution in inter-island areas in Indonesia. Therefore, adequate transportation facilities and infrastructure need to be provided. With the availability of docks, transportation of goods, services or human transportation can be easier and more efficient. In addition, Indonesia's pulai coast has become a tourist attraction. The types of docks in Indonesia are adapted to the facilities and needs of berths and their functions for the island community. The pier construction is planned to use the method of analyzing the data according to the water, seismic data, wind data, the availability of local materials, size and layout planning and structural planning. The purpose of this study is to find out the general shape of the interisland pier structure in Indonesia. The method used in this study is a literature review on the interisland pier in Indonesia. The results of the literature review indicate that there are three forms of pier structure in Indonesia with the most form being the quay form which is dominated by the transportation functions of loading and unloading trade goods, and the form of jetty which is dominated by the human transportation function. The shape of the jetty is generally not only made from concrete foundations and deck plates but also uses local materials.
\end{abstract}

Keywords: Sea Transportation; Dock Construction; Ship Anchored

\section{INTRODUCTION}

Indonesia is a maritime country consisting of islands stretching from Sabang to Merauke, with 17.508 islands. The distance between the islands certainly requires supporting connectivity to support the stability of the nation's economy equally.

Based on data from the Coordinating Ministry for Maritime Affairs, Indonesia has an area of $5,180,053 \mathrm{~km}^{2}$ with a land area of $1,922,570 \mathrm{~km}^{2}(37.11 \%)$ and water area of $3,257,483 \mathrm{~km}^{2}(62.89 \%)$. The data clearly shows that most of Indonesia's territory consists of water. Seeing this, connectivity is very much needed considering Indonesia's geographical condition, which is mostly water (Tedy, 2019).
The dock is a structure in the water which used for haul the ships in order to take and drop off passenger or load and unload the goods. The shapes and dimensions of the dock is depend on the type of ship or boat that anchored. The dock must be planned carefully, therefore it can be dock and moor, and also can carry out activities quickly, smoothly and safely (Triatmodjo, 2009: 195).

Initially the dock in remote area in Indonesia was only an edge where small ships and boats could docked and moored, in order to load and unload goods, take and drop off passengers and other activities like cultural activities. In order to carry out these activities, the dock must be calm against wave disturbance, so when the port was on the banks of rivers, bays or beaches which were naturally protected against wave disruptions. With the development of 
social, economic, and tourism of an area, the need for other living facilities also increases.

According to the Law of the Republic of Indonesia No. 17 of 2008 concerning Shipping, Ports: places consisting of ships and / or ships with a certain limit as a place of activity and commercial activities used as a place for ships to lean, board and / or unloading goods, consisting of terminals and berths which are equipped with safety and shipping facilities and port support activities as well as intra-place transportation and transportation interfaces.

Therefore, an adequate facilities and infrastructure for transportation are needed. Ships that were originally simple and small, along with the development of technology increased to large ships with more sophisticated technology. To support the sea transportation in Indonesian remote area, facilities required infrastructure in the form of a port or dock. This study focuses on the factors that influence the choice of the shape and structure of the pier in the interisland coastline in Indonesia.

\section{METHODS}

The method used in this discussion is a review based on the dock study literature in Indonesia. The discussion begins with an explanation of the theories about the dock. Then the factors that influence dock planning in Indonesia.

In Indonesian waters, including tropical climates, salinity increases from west to east with a range of 30-35 o/oo. In Indonesia ocean water that has a salinity of more than $34 \mathrm{o} / \mathrm{oo}$ is found in the Banda Sea and Arfuru Sea which are thought to originate from the Pacific Ocean (Wyrtki, 1961).

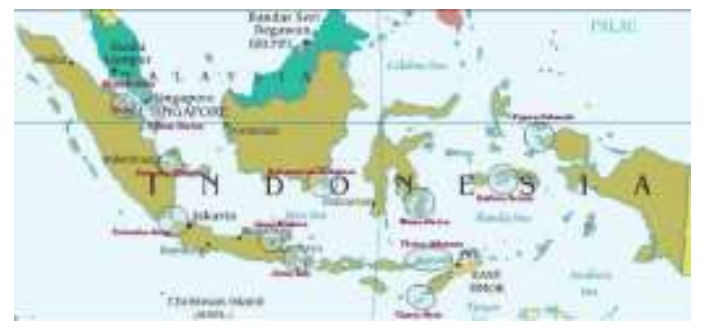

Figure 1. The Location of the inter-island Dock in Indonesia

Progress in the design and implementation of dock construction is very encouraging in the development of dock construction in the world including Indonesia. Some of the most important advances in the design of construction at the dock are the calculation of soil mechanics, wind, currents and waves, breakwaters, prestressed concrete, fender systems, protection against corrosion and advances in the construction industry (Mandi, 2015).

In the planning and implementation of docks many factors must be taken into account in order for the planning to be made effectively and efficiently. Factors that will produce forces include wind, which in the calculation is later determined in accordance with Indonesian load regulations, waves that are determined based on; the character (nature) of waves especially in the dock basin area and also on the waterway, extreme waves such as waves, extreme currents (very strong) and in particular must be given attention to the intersection of currents in the shipping lane and at the inlet, earthquake earth. In designing the dock and its facilities the effects of the earthquake must be taken into account in such a way that these facilities will be able to withstand/ prevent earthquakes perfectly in accordance with Indonesian Earthquake Load regulations, tidal youth, especially the forces of shaking (ups and downs) of large sea levels must be taken into account as well as other forces that influence planning and safety of 
construction must be considered (Mandi, 2015).

These factors are the forces that make the ship move such as wind, waves, currents and earthquakes. In designing the dock and other supporting facilities, it must be taken into account as effectively as possible in order to be able to withstand or prevent an earthquake completely in accordance with Indonesian Earthquake Load regulations. The earthquake resulted in tides and water waves which had to be taken into account in order to maintain safety in the construction.

\section{RESULTS AND DISCUSSION}

The dock structure is divided into two types namely, open construction dock and closed or solid construction dock. An open construction is where the dock is supported by the piles. Whereas closed or solid construction is where there was a boundary between land and sea, separated by a wall that holding the land behind it could be as a wall mass, a kaison, a rip rap, and a retaining wall. Both wharf, pier, and jetty can be built with one of these constructions. (Triatmodjo, 2009). According to Triatmodjo (2009), it can be concluded that the type of dock in Indonesia has similarities to the type of dock in other country, only the terms of local condition are different, like tides, seismic conditions, wind power, water power, and local materials used. In its construction, the dock was built with supporting facilities that relied to a great extent on the types of ships served. It was influencing the type of dock built. The type of dock selected and constructed must be in accordance with the needs or usefulness of the dock, so in its construction can spend less expenditure or in other words, more economical.

In Indonesia, there are three types of docks generally. Those are:
(1) Dolphin dock; the dock used as a berth in the form of dolphin that is above the pile. This type of pier is usually located at a sloping beach location, a bridge trestel is needed to the required depth (Halim, 2017);

(2) Quay wall dock; the quay wall pier was erected with a structure parallel to the beach in the form of a wall consisting of the beach with concrete caisson construction or steel sheet piles. This type of pier is also often referred to as a natural harbor, usually located at a non-sloping beach location not too far from the coastline (Abidin, et al., 2018; Mauluvi, et al., 2017);

(3) Jetty system dock; often referred to as the floating dock, this place is also often used for leaning passenger ships that do not require strong construction to hold heavy cargo goods (Daniar, et al, 2017; Dwifa, et al, 2017; Pratiwi, et al., 2019). From the three, the quay wall is the most in Indonesia, usually for large dock, and the second is jetty system, which is on more remote area. The Dolphin dock was usually established for tourism activities

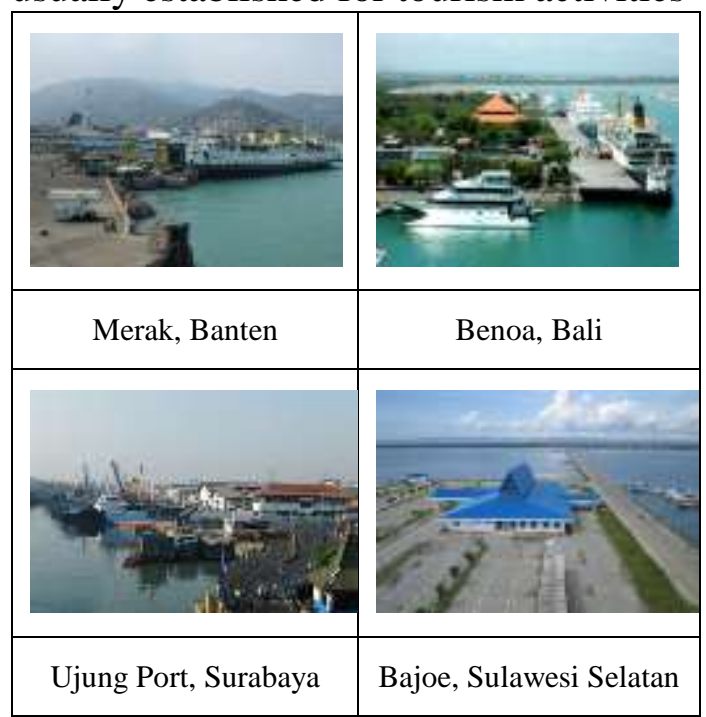

Figure 2. Typical Shape of The dock in Indonesia, Source: Wikipedia

Table 1. The Variances of Dock Types and Dominant factors 


\begin{tabular}{|c|c|c|c|}
\hline $\begin{array}{l}\text { Kalimantan } \\
\text { (Batulicin) }\end{array}$ & Quay & $\begin{array}{l}\text { Fender, } \\
\text { Steel Pile }\end{array}$ & $\begin{array}{l}\text { Slope } \\
\text { Ratio 1:6 }\end{array}$ \\
\hline $\begin{array}{l}\text { East Java } \\
\text { (Madura) }\end{array}$ & Jetty & $\begin{array}{l}\text { Bridge, } \\
\text { Steel Pile }\end{array}$ & Sea Wave \\
\hline $\begin{array}{l}\text { Papua } \\
\text { (Wakde) }\end{array}$ & Jetty & $\begin{array}{l}\text { Fender, } \\
\text { Steel Pile }\end{array}$ & $\begin{array}{l}\text { Sea } \\
\text { Wafe }\end{array}$ \\
\hline $\begin{array}{l}\text { Lombok } \\
\text { (Gili } \\
\text { Trawangan) }\end{array}$ & Dolphin & $\begin{array}{l}\text { Tourism, } \\
\text { Concrete box, } \\
\text { Timber }\end{array}$ & Hurricane \\
\hline $\begin{array}{l}\text { Sumatera } \\
\text { (Enggano) }\end{array}$ & Jetty & $\begin{array}{l}\text { Beach } \\
\text { Break Water }\end{array}$ & Sea Wafe \\
\hline
\end{tabular}

\section{CONCLUSION}

High salinity conditions of seawater, seismic conditions in Indonesia to water wafe, and the function of the pier affect the choice of shape and strength of the inter-island pier. To facilitate the maintenance and ongoing functioning of the dock, most of the jetties are in the form of quay and jetty. The next study should discuss the pier structure planning related to the calculation of the use and maintenance financing in its function to support the economy of the island community.

built parallel to the beach and can be made lined with coastlines or somewhat jutting to the sea in Indonesia, this kind is called a continuous type. The wharf is usually used for the pier of pieces goods or containers where a large open yard is required to guarantee the smooth transit of goods. the planning should take into account the boat moorings, the loading and unloading goods and land transportation facilities. the characteristics of the ship to be anchored affects the length of the wharf and the depth required to embark (Mandi, 2015).

The pier is a type of dock that jutted out into the sea and shaped like a finger. Sometimes it is connected by a mole or trestle and sometimes it's also combined with breakwater pier. In Indonesia, this kind of dock is called a bridge type. In this case, it can be conclude that Pier type is a dock that can be easily found in Indonesia's coastline.

The literature review in the table 1 shows that the choice of the form of inter-island dock structure in Indonesia is influenced by natural factor disorders and the level of durability in serving its function as a transportation infrastructure for goods and people. Jetty shape is the most choice in accordance with the shape of the beach to serve sea transportation.

\section{REFERENCES}

Abidin, Z., Fahturarid, Kisnowo, B. (2018). Perencanaan Struktur Dermaga Peti kemas Kapet Batulicin, di Kalimantan Selatan (Planning of Batulicin Kapet Container Dock Structure, in South Kalimantan), Agregat, 3 (1), 206213.

Daniar, R. P. H., Chomaedhi, Buyung, A. R., Indratmo, D. (2017). Modifikasi Perencanaan Dermaga General Cargo dengan Kapasitas Kapal 10.000 DWT di Kabupaten Sampang, Madura (Modification of General Cargo Dock Planning with 10,000 DWT Boat Capacity in Sampang Regency, Madura). Jurnal Aplikasi Teknik Sipil, 15 (1), 11-16. DOI: http://dx.doi.org/10.12962/j25 79-891X.v15i1.3152

Dwifa, A. D., Naufal, H., Nugroho, P.P., Wibowo, H. (2017). Perencanaan Dermaga Kapal Perintis di Pulau Wakde, Papua (Planning of a Pioneering Pier on Wakde Island, Papua). Jurnal Karya Teknik Sipil, 6 (4), 408-417. 
Halim, H. S. (2017). Scrutinizing Coastal Ecotourism in Gili Trawangan, Indonesia. International Journal of Marine Science, 7 (25), 247-259. DOI:http://dx.doi.org/10.5376/ijms. 2017.07.0025

https://www.dermagaindonesia.co.id/, accesed at May 27, 2019.

https://id.wikipedia.org/wiki/Pelabuhan_ Benoa, accessed at May 25, 2019.

Mandi, N. B. R. (2015). PELABUHAN. Perencanaan dan Perancangan Konstruksi Bangunan Laut dan Pantai. Bali: Buku Arti.

Mauluvi, A.W., Salim, N., Alihudien, A. (2017). Evaluasi Konstruksi Dermaga pada Pelabuhan Perikanan di IPP pancer Kabupaten Banyuwangi (Evaluation of Pier Construction at the Fishery Port in the IPP of Banyuwangi Regency). Universitas Muhammadiyah Jember. http://repository.unmuhjember.ac.id/ 794/1/Artikel.pdf

Pratiwi, R. I., Hanif, F., Sidhiswara, I. B. P. A. (2019). The Absence of Market When The Storm Rages: A Study of walfare among Coastal People in Enggano Island, Indonesia. Proceeding ASEAN Youth Conference.ISSN:2599-2643. http://jurnal.aycppim.id/index.php/a $\mathrm{yc} /$.

Tedy, H. (2019, July 31). Permasalahan dalam Aktivitas Pelabuhan di Indonesia (Problem in Port Activities in indonesia), Supply Chain Indonesia.

https://supplychainindonesia.com/per masalahan-dalam-aktivitaspelabuhan-di-indonesia/

Triatmodjo, B. (2009). Perencanaan Pelabuhan. Yogyakarta: Beta Offset.

Undang-Undang Republik Indonesia Number: 17 Tahun 2008). Pelayaran (Shipping).

Wyrtki, K. (1961). Physical Oceanography of the Southeast Asian Waters. Scripts Institution of Oceanography, The University of California, La Jolla, California. 